\title{
EKSISTENSI PENDIDIKAN ISLAM DI INDONESIA (Perspekstif Sejarah Pendidikan Nasional)
}

\author{
Umar \\ Fakultas Tarbiyah Institut Agama Islam Muhammadiyah Bima \\ Kampus: Jalan Anggrek No. 16, Ranggo Na'e \\ Email: laodeumarPGMI@gmail.com
}

\begin{abstract}
Abstrak:
Pendidikan Islam di Indonesia pada hakikatnya telah berlangsung sejak masuk dan berkembangnya Islam ke negeri ini. Besarnya penerimaan masyarakat terhadap Islam menjadikan agama ini sebagai patron kehidupan masyarakat secara luas yang tentu diimbangi dengan proses belajar untuk mengetahui dan memahami ajaran Islam, sekaligus menjadi bukti konkret lahirnya pendidikan Islam. Bahkan, perlu dicatat bahwasannya manifestasi pendidikan Islam sebagai sub sistem pendidikan nasional, memiliki sejarah penting dalam pengembangan pendidikan Indonesia. Kondisi tersebut, dapat diteaah dari eksistensi pendidikan Islam pada masa penjajahan, masa kemerdekaan, sampai pada proses integrasi pendidikan Islam ke dalam sistem pendidikan nasional. Dengan demikian, pengembangan pendidikan di Indonesia, tidak terpisahkan dari keberadaan pendidikan Islam yang mengakar dalam tradisi serta ritualisasi keagamaan masyarakat muslim Indonesia.
\end{abstract}

\begin{abstract}
:
The concept of Islamic education in Indonesia in fact has been ongoing since the incoming and development of Islam itself. Acceptance of Islam as a patron of life, of course offset by the process of learning to know and to understand the teachings of Islam, as well as a concrete evidence of the birth of Islamic education. In fact, it should be noted that manifestation of Islamic education as a sub system of national education has historically been important in the development of education in Indonesia. That condition is able analyzed of the existence of Islamic education during the colonial era, the time of independence, to the process of integration of Islamic education into the national education system. Thus, the development of education in Indonesia is inseparable from the existence of Islamic education that is rooted in tradition and ritualized religious muslim community in Indonesia.
\end{abstract}

\section{Kata kunci: \\ Sejarah Indonesia, Pendidikan Islam}

ISLAM merupakan komponen penting yang turut membentuk dan mewarnai corak kehidupan masyarakat Indonesia. Keberhasilan Islam menembus kehidupan masyarakat Indonesia serta menjadikan dirinya sebagai agama utama adalah prestasi luar biasa mengingat posisi geografi Indonesia yang jauh dari wilayah asal Islam yaitu jazirah Arab. Karena jarak tersebut, tidak ditemukan pada awal masuk dan dimulainya penyebaran Islam di Nusantara suatu metode atau organisasi dakwah yang dianggap mapan dan efektif untuk memperkenalkan Islam kepada masyarakat luas. ${ }^{1}$ Berkembangnya Islam yang memengaruhi dimensi kehidupan masyarakat Indonesia, 
sekaligus menjadi titik awal lahirnya konsep pendidikan Islam di Indonesia. Menurut Mahmud Yunus, dalam Hasbulah, sejarah pendidikan Islam sama tuanya dengan masuknya agama tersebut ke Indonesia. ${ }^{2}$ Model pendidikan agama yang berkembang sejak awal tersebut menunjukkan suatu pola yang menyesuaikan dengan konteks kesederhaan dan kesahajaan.

Konteks sederhana dan dimaknai sebagai proses belajar yang menekankan pada aspek kesehajaan atau tidak bermewah-mewahan. ${ }^{3}$ Bahkan, kebutuhan terhadap pendidikan telah mendorong masyarakat muslim Indonesia mengadopsi dan mentransfer lembaga keagamaan maupun sosial yang sudah ada ke dalam lembaga pendidikan Islam di Indonesia. Di Jawa, umat Islam mengadopsi lembaga keagamaan Hindu-Budha menjadi lembaga pendidikan pesantren. Di Minangkabau mengambil alih serau sebagai peninggalan adat menjadi lembaga pendidikan Islam. Demikian pula masyarakat Aceh yang mentransfer lembaga masyarakat maunasah sebagai lembaga pendidikan Islam. ${ }^{4}$

Sejak Indonesia merdeka, pesantren berkembang semakin dinamis ke arah pesantren modern dengan ciri klasikal. Pesantren, berkembang dari bentuk tradisional (salafi) berkembang kepada pesanten modern (khalafi). Kemoderenan dapat dilihat dari tiga segi: pertama, mata pelajaran telah seimbang antara materi ilmu-ilmu agama dengan materi ilmu-ilmu umum; kedua, metode pembelajaran bervariasi, tidak lagi semata-mata hanya memakai metode wetonan atau halaqah dan sorogan; dan ketiga, dikelola berdasarkan prinsip-prinsip menajeman pendidikan. ${ }^{5}$

Berangkat dari gambaran teoritis di atas, penulis berusaha menguraikan satu tulisan yang berkenaan dengan topik bahasan "eksistensi pendidikan Islam di Indonesia: perspekstif sejarah pendidikan nasional".

\section{PEMBAHASAN}

\section{Sejarah Perkembangan Pedidikan Islam di Indonesia}

Menelusuri beberapa literatur yang menguraikan tentang sejarah pendidikan Islam, dijelaskan bahwa pertumbuhan dan perkembangan pendidikan Islam di Indonesia telah melalui periodisasi yang sangat panjang. Periodisasi tersebut dapat diklasifikasikan ke dalam tiga bagian utama: masuknya Islam ke Indonesia, pendidikan Islam zaman penjajahan, dan pendidikan Islam zaman kemerdekaan.

\section{Masuknya Islam ke Indonesia}

Berdasarakan penuturan sejarah, Islam telah masuk ke Indonesia diperkirakan pada abad ke-7 M dan menyebar luas sekitar abad ke-13 M. Perluasan Islam itu ditandai dengan berdirinya kerajaan-kerajaan Islam awal seperti Kesultanan Perlak dan Samudra Pasai di Aceh pada tahun 1292 dan tahun 1297. Melalui pusat-pusat perdagangan di pantai Sumatera bagia utara dan melalui jalur perdagangan Malaka, agama Islam kemudian menyebar ke pulau Jawa dan seterusnya ke Indonesia bagian timur. Masuknya Islam ke Indonesia dan peralihan agama Hindu ke Islam, umumnya berlangsung secara damai. ${ }^{6}$ 
Fachry Ali dan Bachtiar Efendi dalam Hasbullah menguraikan tiga faktor utama yang mempercepat proses penyebaran Islam di Indonesia. Pertama, ajaran Islam menekankan prinsip ketauhidan dalam sistem ketuhanannya, yakni suatu prinsip yang secara tegas melaksanakan ajaran untuk mempercayai Tuhan Yang Maha Tunggal. Selain itu, Islam juga mengajarkan prinsip keadilan dan persamaan dalam tata hubungan kemasyarakatan. Ajaran-ajaran tersebut merupakan ajaran baru yang bertentangan dengan sistem hubungan kemasyarakatan yang berlaku saat Islam datang. Memilih Islam pada dasarnya memilih kehidupan keagamaan yang berasas persamaan, kebebasan, dan keadilan. Kedua, daya lentur atau fleksibilitas ajaran Islam dalam artian Islam sebagai agama merupakan kodifikasi nilai-nilai ajaran yang universal. Ketiga, dalam sejarah perkembangannya di Nusantara, Islam menjadi suatu institusi dominan untuk menghadapi dan melawan ekspansi Barat melalui bangsa Portugis, Inggris, dan Belanda dalam penyebaran agama Kristen ke dunia timur. ${ }^{7}$

Pandangan senada diungkap oleh Mukti Ali bahwa suksesnya penyiaran Islam di Indonesia karena ajaran-ajarannya mudah dimengerti serta kesanggupan para pembawa Islam "tempo dulu" dalam memberikan konsesi terhadap adat kebiasaan yang ada dan hidup dalam masyarakat. ${ }^{8}$ Lebih lanjut, Saifuddin Zuhri menjelaskan proses pembentukan dan penyebaran masyarakat Islam di Indonesia melalui beberapa macam interaksi antara satu dengan yang lainya seperti kontak jual beli (perdagangan), kontak perkawinan, dan kontak dakwah langsung, baik secara individu maupun kolektif. ${ }^{9}$ Di sinilah proses pendidikan Islam berlangsung dalam pola yang masih sederhana. Materi yang pertama kali diajarkan adalah kalimat syahadah. Pilihan materi ini didorong oleh doktrin bahwa bersyahadat berarti telah menjadi Islam. Para penganjur ajaran agama Islam saat itu, melaksanakan pendidikan Islam secara berangsur-angsur dengan cara yang mudah, sedikit demi sedikit, sehingga orang tersebut mampu menguasai sepenuhnya inti ajaran Islam, yakni melaksankan lima rukun Islam dan meyakini enam rukun iman. ${ }^{10}$

Dengan demikian, dapat diasumsikan bahwa masuknya Islam ke Indonesia telah mampu merubah fondasi dan pola kehidupan masyarakat yang terbelenggu oleh perbedaan kasta dalam ajaran Hindu seperti membedakan antara kelompok bangsawan dan jelata, menjadi asas persamaan dan keadilan di mata Tuhan. Hal ini mendorong proses penyebaran Islam berkembang begitu pesat dan cepat di seluruh pelosok nusantara. Faktanya, penerimaan Islam sebagai agama juga diikuti dengan keinginan belajar agama sehingga pelaksanaan pengajaran tentang inti ajaran Islam merupakan esensi dari proses pendidikan Islam di Indonesia.

\section{Pendidikan Islam Zaman Penjajahan}

Bentuk penaklukan bangsa Barat atas dunia Timur dimulai dengan jalan perdagangan, kemudian dengan kekuatan militer dan akhirnya pendudukan atau penjajahan. Selama masa penjajahan Barat, misi westernisasi terjadi secara masif di seluruh wilayah Indonesia. Di satu sisi, kedatangan bangsa penjajah telah membawa kemajuan di bidang teknologi. Sisi lainnya, penjajahan berdampak pada penjarahan potensi-potensi alam di tanah jajahannya demi kepentingan imperialisme. ${ }^{11}$ Dalam urusan 
penyelenggaraan pendidikan masyarakat pribumi, cenderung dipolitisasi demi mengokohkan kepentingan kekuasaan mereka di tanah jajahannya.

\section{a. Pendidikan Zaman Belanda}

Belanda mulai menjajah Indonesia pasa tahun 1619, yaitu ketika Jan Pieter Zoon Coen menduduki Jakarta dan dilawan oleh Sultan Agung Mataram. Setelah Belanda dapat mengatasi perlawanan-perlawanan dari para tokoh-tokoh politik dan agama seperti Pangeran Diponegoro, Imam Bonjol, Tengku Cik Di Tiro, Pangeran Antasari, Sultan Hasanuddin dan lain-lain, maka sejarah kolonialisme Indonesia mengalami fase yang baru, yakni Belanda secara politik sudah dapat menguasai Indonesia. Rajaraja di daerah masih ada, tetapi tidak dapat berkuasa penuh, baik di wilayahnya maupun di bidang ketatanegaraannya. Kekuasaan secara politik, ekonomi, dan sosial budaya praktis berada di tangan penjajajah. Selain itu, Belanda juga berkuasa mengatur pendidikan dan kehidupan beragama, sesuai dengan prinsip-prinsip kolonialisme, westernisasi, dan kristenisasi. ${ }^{12}$

Pemerintahan Belanda melalui Gubernur Jenderal Van Den Capellen pada tahun 1819 M. mengambil inisiatif merencanakan berdirinya sekolah dasar bagi pribumi agar dapat membantu pemerintahan Belanda. Surat edaran kepada para bupati disebutkan bahwa dianggap penting untuk secepat mungkin mengadakan peraturan pemerintah yang menjamin meratanya kemampuan membaca dan menulis bagi penduduk pribumi agar mereka lebih mudah untuk dapat menaati undang-undang dan hukum negara. Bagi pihak Belanda, pendidikan Islam yang ada di pondok pesantren, masjid, musalla dan lain sebagainya dianggap tidak membantu pemerintah Belanda karena para santri pondok dianggap buta huruf Latin. ${ }^{13}$

Pada tahun 1882 pemerintah Hindia Belanda membentuk badan khusus yang bertugas mengawasi kehidupan beragama dan pendidikan Islam yang disebut priesterradden. Atas nasehat badan inilah, pada tahun 1905 pemerintah Belanda mengeluarkan peraturan yang isinya membatasi ruang mengajar dan untuk menjadi guru harus meminta izin terlebih dahulu. Klimaksnya, pada Tahun 1925 Belanda mengeluarkan peraturan lebih ketat bahwa tidak semua orang (dimaksud Kyai) boleh memberikan pengajaran mengaji. Peraturan itu disebabkan tumbuhnya organisasi pendidikan Islam, seperti Muhammadiyah, Syarikat Islam, Al-Irsyad, Nahdlatul Wathan, dan lain-lain. Tahun 1932 keluar pula peraturan yang dapat memberantas dan menutup madrasah dan sekolah yang tidak ada izinya yang disebut ordonansi sekolah liar. Peraturan ini muncul setelah gerakan nasionalisme-Islamisme pada tahun 1928 berupa sumpah pemuda. Untuk menjaga dan menghalangi masuknya pelajaran agama di sekolah umum yang kebanyakan muridnya beragama Islam, pemerintah Belanda mengeluarkan peraturan yang disebut "netral agama". ${ }^{14}$

Penjelasan di atas menunjukkan bahwa proses pelaksanaan pendidikan Islam di Nusantara pada masa penjajahan Belanda, ruang gerak dan pengembangannya dibatasi dengan regulasi yang diikat oleh pemerintah kolonial. Regulasi itu terbit oleh karena pemerintah kolonial Belanda menganggap sekolah-sekolah dengan label Islam sebagai basis pemberontakan dan perlawanan terhadap kekuasaan. 


\section{b. Pendidikan Zaman Jepang}

Jepang menduduki Indonesia setelah berhasil mengalahkan pasukan Belanda dalam perang Asia Timur. Jepang menguasai Indonesia tepatnya pada tahun 1942 melalui Tarakan dan Minahasa berturut-turut kemudian wilayah lain di seluruh $\mathrm{Nu}-$ santara. Awalnya pemerintahan Jepang menunjukan sikap seakan-akan membela kepentingan Islam sebagai siasat untuk kepentingan Perang Dunia II. ${ }^{15}$ Untuk mendekati umat Islam Indonesia, mereka mengeluarkan beberapa kebijakan antara lain:

1) Kantor urusan agama yang pada zaman Belanda disebut kantor Voor Islamistishe Saken yang dipimpin oleh orientalis Belanda diubah menjadi Sumubi yang dipimpin ulama Islam, yaitu K. H. Hasyim Asy'ari dari Jombang dan di daerahdaerah disebut Sumuka.

2) Pondok pesantren yang besar-besar mendapat kunjungan dan bantuan dari pembesar Jepang.

3) Sekolah-sekolah negeri diberi pelajaran budi pekerti yang isinya identik dengan ajaran agama.

4) Membentuk barisan Hisbullah yang memberi latihan dasar kemiliteran pemuda Islam (santri-santri) dipimpin oleh K. H. Zainul Arifin.

5) Mengizinkan berdirinya Sekolah Tinggi Islam dipimpin oleh K. H. Wahid Hasyim, Kahar Muzakkir, dan Bung Hatta.

6) Ulama Islam bekerja sama dengan pimpinan nasionalis membentuk Barisan Pembela Tanah Air (PETA). Organisasi pembela tanah air inilah yang menjadi inti dari TNI sekarang.

7) Umat Islam mendirikan Majelis Syuro Muslimin Indonesia (Masyumi) yaitu merupakan komponen penting yang turut membentuk dan mewarnai corak kehidupan masyarakat Indonesia. ${ }^{16}$

Meskipun pemerintahan Jepang berusaha mengambil hati umat Islam dengan memberikan kebebasan dalam melaksanakan praktik agama dan mengembangkan pendidikan, ulama tidak mudah untuk tunduk pada pemerintahan Jepang apabila hal tersebut bertolak belakang dengan akidah Islam. Misalnya perjuangan K. H. Ahmad Dahlan dan para santrinya dalam menentang kebijakan kufur pemerintahan Jepang yang memerintahkan setiap orang harus menghadap ke Tokyo setiap pukul 07.00 untuk menghormati Kaisar Jepang yang mereka anggap keturunan Dewa Matahari. Akibat sikap tersebut, beliau ditangkap dan dipenjarakan oleh pemerintah Jepang selama 8 tahun. ${ }^{17}$ Namun, mencermati kebijakan yang ditunjukkan oleh pemerintahan Jepang, berkenaan dengan pengembanan pendidikan Islam di Indonesia, paling tidak memberi gambaran bahwa pelaksanaan pendidikan Islam pada saat itu lebih dinamis yang berbeda dengan masa penjajahan Belanda. Meski upaya pembentukan sikap nasioanlisme Islam yang dilakukan oleh pemerintahan Jepang terhadap masyarakat pribumi memiliki muatan positif, akan tetapi pada substansinya kebijakan tersebut menekankan kepentingan Jepang dalam mengatasi Perang Dunia II atau Perang Asia Timur Raya yang dipimpinnya. 


\section{Pendidikan Islam Zaman Kemerdekaan}

Pendidikan Islam pasca kemerdekaan dapat dibagi melalui tiga periode. Pertama, pelaksanaan pendidikan Islam semenjak Indonesia merdeka sampai tahun 1965 yang dikenal dengan periode Orde Lama. Kedua, pelaksanaan pendidikan Islam mulai tahun 1965 sampai sekarang yang dikenal dengan periode Orde Baru. Ketiga, pelaksanaan pendidikan Islam mulai tahun 1998 sampai sekarang atau disebut periode reformasi. Untuk kebutuhan analisis, tulisan ini hanya memuat keadaan pendidikan Islam di Indonesia dalam dua periode pertama saja dengan asumsi keadaannya pada periode ketiga sedang berproses. Dalam persepsi penulis, pemetaan pembahasan tentang pelaksanaan pendidikan Islam setelah merdeka dimaksudkan untuk melihat pola kebijakan pemerintah dalam hal menyelenggarakan pendidikan Islam.

\section{a. Pendidikan Islam periode Orde Lama}

Penyelenggaraan pendidikan Islam setelah Indonesia merdeka pada tanggal 17 Agustus 1945 sudah dilaksanakan dan mendapat perhatian serius dari pemerintah dengan dikeluarkannya beberapa kebijakan, di antaranya: pemerintah memberikan penghargaan tinggi bagi pendidikan agama Islam, termasuk lembaga-lembaga Islam yang sudah ada. Pada tanggal 22 Desember 1945 BPKNIP (Badan Pekerja Komite Nasional Indonesia Pusat) mengumumkan (berdasarkan berita RI tahun No. 4 dan 4 hal. 20 kolom 1) bahwa "Memajukan dunia pendidikan dan pengajaran di langgarlanggar dan madrasah berjalan terus dan diperpesat." Berikutnya tanggal 27 Desember 1945 BPKNIP menyarankan agar pendidikan agama di sekolah mendapatan tempat yang teratur, seksama, dan mendapat perhatian yang semestinya. Selain itu BPKNIP menyarankan agar lembaga pendidikan madarasah dan pondok pesantren mendapat bantuan material dari pemerintah karena madrasah dan pondok pesantren pada hakikatnya adalah satu alat dan sumber pendidikan yang mencerdaskan rakyat serta sudah berakar dalam masyarakat Indonesia. ${ }^{18}$

Selanjutnya, pendidikan Islam untuk sekolah umum mulai diatur secara resmi oleh pemerintah pada bulan Desember 1946 dengan keluarnya peraturan bersama dua menteri yaitu Menteri Agama dan Menteri Pendidikan dan Pengajaran yang menetapkan bahwa pendidikan agama diberikan mulai kelas IV SR (Sekolah Rakyat) sampai kelas VI. Pada masa itu kondisi negara belum stabil sehingga SKB dua menteri belum berjalan sebagaimana mestinya. Kemudian pada tahun 1950 di saat keadaan negara sudah stabil di seluruh Indonesia, barulah rencana pendidikan agama untuk seluruh wilayah Indonesia makin disempurnakan dengan dibentuknya pantia bersama yang dipimpin oleh Prof. Mahmud Yunus dari Departemen Agama dan Mr. Hadi dari Departemen Pendidikan dan Kebudayaan. Hasil dari panitia itu adalah SKB yang dikeluarkan pada bulan Januari 1951 yang isinya sebagai beriku:19

1) Pendidikan agama diberikan mulai kelas IV Sekolah Rakyat.

2) Di daerah-daerah yang masyarakat agamanya kuat (misalnya sumatera, Kalimantan dan lain-lain) maka pendidikan agama diberikan mulai kelas I SR dengan catatan bahwa pengetahuan umum tidak boleh kurang dibandingkan sekolah lain yang pendidikan agamanya diberikan mulai kelas IV. 
3) Di sekolah lanjutan pertama dan tingkat atas (umum dan kejuruan) diberikan pendidikan agama sebanyak 2 jam per minggu.

4) Pendidikan agama diberikan kepada para murid sedikitnya 10 orang dalam satu kelas dan mendapat izin dari orang tua/walinya.

5) Pengangkatan guru agama, biaya pendidikan agama, dan materi pendidikan agama ditanggung oleh Departemen Agama.

Selanjutnya, dalam hal penyempurnaan kurikulum, pemerintah membentuk panitia yang dipimpin oleh K. H. Imam Zarkasyi dari pondok Gontor Ponorogo dan disahkan oleh Menteri Agama pada tahun 1952. ${ }^{20}$ Dengan demikian, poin penting dipahami bahwa penyelenggaran pendidikan Islam pada masa pemerintahan Orde Lama secara konstitusional sudah diberlakukan dengan baik. Meski demikian, bila ditelaah lebih mendalam bentuk kebijakan yang dikeluarkan terdapat indikasi pengelompokkan pendidikan yakni, pendidikan agama dan pendidikan umum bila dilihat dari pembentukan departemen yang ditugaskan untuk menyelenggarakan pendidikan pada saat itu. Kondisi tersebut menegaskan bahwa dualisme pendidikan di Indonesia yang termanifestasi dalam tugas Kementerian Agama dan Kementerian Pendidikan saat ini, merupakan warisan sejarah pada masa pemerintahan Orde Lama.

\section{b. Pendidikan Islam pada Periode Orde Baru}

Sejak ditumpasnya pemberontakan PKI pada tanggal 1 Oktober 1965, bangsa Indonesia telah memasuki fase baru yang dinamakan Orde Baru. ${ }^{21}$ Pemerintahan Orde Baru bertekad sepenuhnya untuk kembali kepada Undang-Undang Dasar 1945 dan melaksanakannya secara murni. Pemerintah dan rakyat membangun manusia seutuhnya untuk masyarakat Indonesia seluruhnya yakni membangun aspek rohani dan jasmani individu untuk kehidupan yang baik di dunia dan akhirat. Untuk merealisasikan tekad tersebut, pemerintah Orde Baru menetapkan beberapa kebijakan kaitannya dengan pelaksanaan pendidikan agama, antara lain:22 1) Memperkokoh kehidupan beragama dan pendidikan agama dalam struktur organisasi pemerintah maupun masyarakat. Melalui sidang-sidang MPR yang menyusun GBHN pada tahun 1973-1978 dan 1983 ditegaskan bahwa pendidikan agama menjadi mata pelajaran wajib di setiap sekolah negeri dalam semua jenjang pendidikan. 2) Ditetapkannya peraturan pola umum PELITA IV bidang agama dan kepercayaan terhadap Tuhan Yang Maha Esa yang dinyatakan sebagai berikut:

Dengan semakin meningkatnya dan meluasnya pembangunan, maka kehidupan keagamaan dan kepercayaan terhadap Tuhan Yang Maha Esa harus semakin diamalkan, baik dalam kehidupan pribadi maupun kehidupan sosial masyarakat. Diusahakan supaya terus bertambah sarana-sarana yang diperlukan bagi pengembangan kehidupan dan kepercayaan kepada Tuhan Yang Maha Esa termasuk pendidikan agama yang dimasukkan ke dalam kurikulum di sekolahsekolah mulai dari sekolah dasar sampai universitas-universitas negeri. 23

Berdasarkan uraian di atas, dapat dikatakan bahwa penyelenggaraan pendidikan Islam pada pemerintahan masa Orde Baru bila dilihat dari beberapa kebijakan 
yang dikeluarkan pada intinya menekankan pada penguatan secara konstitusional serta menyempurnakan pelaksanaan pendidikan Islam pada masa Orde Lama.

\section{Bentuk Sekolah dan Organisasi Pendidikan Islam di Indonesia}

Terbentuknya organisasi Islam di Indonesia banyak disebabkan tumbuhnya sikap patriotisme dan rasa nasionalisme sebagai respons terhadap kepincangan-kepin cangan yang ada di kalangan masyarakat pada akhir abad ke-19 yang mengalami kemunduran total sebagai akibat eksploitasi politik pemerintah kolonial Belanda. ${ }^{24}$ Para pemimpin pergerakan nasional dengan kesadaran penuh ingin mengubah keterbelakangan rakyat Indonesia melalui langkah progresif dengan membangun organisasi sekolah. Maka berdirilah sekolah-sekolah yang memiliki dua corak. Pertama, corak sekolah dengan haluan politik seperti Taman Siswa yang mula-mula didirikan di Yogyakarta, Sekolah Serikat Rakyat di Semarang yang berhaluan komunis, Ksatria Institut yang didirikan oleh Douwes Dekker (Dr. Setiabudi di Bandung) dan Perguruan Rakyat di Jakarta dan Bandung. Kedua, corak sekolah sesuai dengan tuntutan/ ajaran agama (Islam), seperti sekolah-sekolah Serikat Islam, sekolah-sekolah Muhammadiyah, Sumatera Tawalib di Padang Panjang, sekolah-sekolah Nahdhatul Ulama, sekolah-sekolah Persatuan Umat Islam (PUI), sekolah-sekolah Al Jami'atul Wasliyah, sekolah-sekolah Al-Irsyad, sekolah-sekolah Normal Islam dan masih banyak lagi sekolah-sekolah lain yang didirikan oleh organisasi Islam ataupun oleh perorangan di berbagai kawasan kepulauan Indonesia, baik dalam bentuk pondok pesantren maupun madrasah. ${ }^{25}$

Selain berdirinnya lembaga sekolah yang orientasinya dalam ranah pendidikan Islam secara formal, berdiri pula beberapa organisasi berdasarkan sosial keagamaan yang banyak melakukan aktivitas kependidikan Islam, antara lain:

a. Al-Jami' at Al-Khairiyah, suatu organisasi yang lebih dikenal dengan nama Jami'at Khair didirikan di Jakarta pada tanggal 17 Juli 1905. Anggota organisasi ini mayoritas orang-orang Arab. Dua bidang utama yang diperhatikan oleh organisasi ini adalah pembinaan satu sekolah pada tingkat dasar dan pengiriman anak-anak muda ke Turki untuk melanjutkan studi. ${ }^{26}$

b. Muhammadiyah termasuk organisasi yang berdasarkan agama Islam, sosial, dan kebangsaan. Organisasi ini didirikan di Yogyakarta pada tanggal 8 Dzulhijjah 1330 H. oleh K. H. Ahmad Dahlan. Organisasi ini bertujuan untuk menyebarluaskan pendidikan Islam. ${ }^{27}$

c. Nahdhatul Ulama disingkat NU didirikan di Surabaya pada tanggal 31 Januari $1926 \mathrm{M}$ bertepatan dengan tanggal 16 Rajab $1444 \mathrm{H}$ oleh kalangan ulama penganut mazhab dan sering kali menyebut dirinnya sebagai golongan Ahlussunah Waljama'ah yang dipelopori oleh K. H. Hasyim Asy'ari dan K. H. Abdul Wahab Hasbullah. ${ }^{28}$

d. Perserikatan Ulama, merupakan perwujudan dari lahirnya gerakan-gerakan pembaharuan di Indonesia. Kehadiran Perserikatan Ulama atas dasar inisiatif K.H. Abdul Halim pada tahun 1911 M. 
e. Persatuan Islam disingkat PERSIS yang didirikan di Bandung pada tanggal 17 September 1923 M oleh K. H. Zamzam. PERSIS memberikan perhatiannya sangat besar di bidang pendidikan. Dalam pendidikan, PERSIS mendirikan madrasah dimaksudkan untuk melayani anak-anak anggotanya. 29

Bilamana ditelaah muatan tujuan dan orientasi terbentuknya beberapa orgainisasi-organisasi di atas, baik dalam bentuk lembaga sekolah maupun organisasi non formal lainnya, secara umum organisasi tersebut mempunyai peranan yang sama sebagai wadah pengembangan diri sekaligus untuk memperkokoh pemahaman terhadap Islam. Bahkan, bila ditelusuri lebih jauh beberapa organisasi tersebut telah berperan penting dalam upaya memperjuangkan kemerdekaan, sekaligus menjadi pelopor dalam pengembangan pendidikan Islam di Indonesia.

\section{Landasan Pengembangan Pendidikan Islam di Indonesia}

Proses pengembangan pendidikan Islam di Indonesia sejatinya memiliki akar yang jelas sebagai pijakan operasionalnya. Bila merujuk penjelasan beberapa literatur bahwa landasan pendidikan Islam, paling tidak dapat diklasifkasikan dalam dua garis besar yaitu: landasan dasar ideal dan landasan dasar operasional.

\section{a. Landasan dasar ideal}

Landasan ideal yang dimaksud adalah landasan yang menjadi dasar pokok pendidikan Islam yaitu Alquran dan hadis yang kemudian dikembangkan menjadi ijtihad dan ijma' para ulama. Selain itu, perundang-undangan yang berlaku di Indonesia seperti; Undang-Undang Dasar RI 1945 pasal 29 ayat 1, GBHN Tahun 1993 Bidang Agama dan Kepercayaan terhadap Tuhan Yang Maha Esa No. 22, dan Undang-Undang RI No. 20 Tahun 2003 pasal 30 tentang Sistem Pendidikan Nasional juga merupakan landasan ideal pelaksanaan pendidikan Islam dan sekaligus sebagai payung hukum penyelenggaraan pendidikan Islam di Indonesia. Undang-undang dapat diartikan sebagai peraturan hukum yang tidak disebutkan secara tegas di dalam Alquran, namun dalam praktiknya, tidak boleh bertentangan dengan al-Qur'an serta hadis dan tentunya bertujuan untuk kemaslahatan umat tanpa adanya diskriminasi. ${ }^{30}$

\section{b. Landasan Dasar Operasional}

Landasan operasional yang dimaksud adalah landasan dasar tentang implementasi dari landasan dasar ideal, meliputi landasan historis, landasan sosial, landasan psikologi, dan landasan filosofis, yang diuraikan berikut ini:

1) Landasan historis

Kondisi pendidikan yang terjadi saat ini tidak terlepas dari pengalaman masa lalu dalam bidang pendidikan, kondisi sosial, budaya, dan keyakinan yang ada pada masa lalu penuh dengan muatan nilai-nilai positif baik yang relevan maupun tidak relevan dengan kehidupan generasi sekarang, Di samping itu, sejarah mengandung nilai-nilai yang cukup untuk dijadikan pelajaran.

2) Landasan sosial

Konsepsi pendidikan sebagai ruang interaksi manusia yang hanya bisa berjalan melalui jaringan kemanusiaan. Menurut H. J. langeveld menjelaskan bahwa manusia 
itu pada hakikatnya adalah homo homini socius. Kondisi masyarakat yang dinamis dan statis umumnya memengaruhi kondisi pendidikan masyarakatnya. Maka, visi dan misi pendidikan adalah membebaskan manusia dari kungkungan penindasan, menggerakkan manusia untuk hidup merdeka dan bebas mewujudkan hidup yang damai dan harmonis.

3) Landasan psikologis dan filosofis

Pendidikan melibatkan dua aspek psikologi yaitu aspek mengajar dan belajar. Muatan psikologi dalam pengembangan pendidikan Islam tidak dapat dipisahkan dengan nilai-nilai praksisnya. Sedang muatan landasan filosofis menekankan tentang pandangan hidup manusia yang paling mendasar yaitu kemanusiaan itu sendiri. Sedangkan, landasan filosofi mengandung nilai-nilai yang bersumber dari Tuhan dan manusia (humanisme-teosentris). ${ }^{31}$

\section{Sistem dan Isi Pendidikan Islam di Indonesia}

Historiografi perkembangan pendidikan Islam di Indonesia tidak dapat dipisahkan dengan sejarah perjuangan kemerdekaan negara ini. Keberadaan pendidikan Islam Indonesia juga erat berhubungan dengan sistem dan isi pendidikan Islam secara umum. Sistem pendidikan yang dimaksud dapat dipahami sebagai tata cara atau metode yang digunakan untuk mengimplementasikannya di lapangan sedangkan isi pendidikan menekankan materi, bahan, dan sumber penyelenggaraan pendidikan itu.

\section{a. Sistem pendidikan Islam Indonesia}

Pada awal perkembang agama Islam di Indonesia, pendidikan Islam dilaksanakan secara informal. Sistem pendidikan Islam informal ini berlangsung di lingkungan masyarakat. Pelaksanaan sistem pendidikan Islam secara informal berhubungan langsung dengan pola penyebaran Islam di Indonesia, terutama proses pendidikan Islam yang dilakukan di lembaga seperti surau, langgar atau masjid-masjid. Selanjutnya sistem pendidikan Islam berkembang menjadi sistem pendidikan formal melalui institusi pondok pesantren dan madrasah atau sekolah yang berdasar keagamaan. ${ }^{32}$

\section{b. Isi pendidikan Islam di Indonesia}

Membicarakan isi pendidikan Islam di Indonesia tidak terpisahkan dari tujuan yang hendak dicapai oleh pendidikan Islam. Tujuan pendidikan Islam sebagaimana hasil Konferensi Dunia Pertama tentang Pendidikan Islam pada tahun 1977 menegaskan bahwa tujuan akhir pendidikan Islam adalah terbentuknya manusia yang menyerahkan diri secara mutlak kepada Allah swt. ${ }^{33}$ Berangkat dari muatan tujuan pendidikan Islam tersebut, maka isi pendidikan Islam menyentuh persoalan pokok-pokok aqidah dan ibadah yang mudah dipahami seperti salat, puasa, dan membaca Alquran. ${ }^{34}$ Literature lain menyebutkan isi pendidikan Islam mencakup dua aspek meliputi pokok: (1) pengajian Alquran yang isinya seperti; huruf hija'iyah dan membaca Alquran, ibadah (praktek dan rukunnya), keimanan, dan akhlak. (2) pengajian kitab, isinya seperti ilmu saraf, ilmu nahu, ilmu fikih, ilmu tafsir dan lain-lain. ${ }^{35}$ 
Berdasarkan dari uraian di atas, ada dua poin penting yang dapat dipahami: pertama, penjelasan tentang sistem pendidikan Islam yang substansinya menekankan tentang metodologi pengajaran pendidikan Islam masih sederhana yang keserupaannya dapat ditelusuri mulai fase awal masuk Islam sampai era pembaharuan pendidikan Islam. Kedua, penjelasan tentang isi pendidikan Islam yang cenderung menekankan pada spesifikasi materi ajar yang terdapat dalam pendidikan Islam. Bahkan, dalam persepsi penulis titik tekan dari isi pendidikan Islam mengarah pada pembelajaran tentang nilai subtantif ajaran Islam yang mencakup lima rukun Islam dan enam rukun Iman.

\section{Integrasi Pendidikan Islam ke dalam Sistem Pendidikan Nasional}

Kedudukan pendidikan Islam di Indonesia sebagai sub-sistem pendidikan nasional telah mengalami perubahan dan berkembang secara kontinu. ${ }^{36}$ Perubahan dimulai dari munculnya kesadaran dari berbagai pihak untuk mengintegrasikan pendidikan Islam ke dalam sistem pendidikan nasional. Integrasi pendidikan dapat dimaknai sebagai upaya pemaduan atau penggabungan dalam menyelenggarakan pendidikan. Secara yuridis, tercatat beberapa kebijakan pernah ditetapkan pemerintah guna mengintegrasikan pendidikan Islam ke dalam pendidikan nasional seperti; pada tahun 1975 dikeluarkanya Surat Keputusan Bersama (SKB) Tiga Menteri, yakni Menteri Pendidikan dan Kebudayaan, Menteri Dalam Negeri, dan Menteri Agama tentang peningkatan mutu Madrasah. Melalui SKB ini, madrasah diharapkan memperoleh posisi yang sama dengan sekolah-sekolah umum dalam sistem pendidikan nasional sehingga lulusan dari madrasah dapat melanjutkan studi atau pindah sekolah ke sekolah-sekolah umum, dari tingkat dasar sampai perguruan tinggi, mengingat pelajaran umum di kedua lembaga tersebut memiliki mutu yang sama. Di dalam SKB ini, juga dirumuskan mengenai batasan penjenjangan madrasah, yaitu madarasah ibtidaiyah (MI), madarasah tsanawiyah (MTs), dan Madrasah Aliyah (MA). ${ }^{37}$

Kemudian dilanjutkan pada tahun 1984 dengan terbitnya Surat Keputusan Bersama Menteri Pendidikan dan Kebudayaan dengan Menteri Agama No. 9299/U/ 1984 dan No. 45 Tahun 1984, tentang pengaturan pembakuan Kurikulum Sekolah Umum dan Kurikulum Madrasah. Surat keputusan bersama (SKB) tahun 1984 M ini merupakan tindak lanjut dari SKB Tiga Menteri tahun 1975. Tujuannya tidak hanya menyamakan madrasah dengan sekolah-sekolah umum dalam penjenjangan dan mutu pengetahuan saja, tetapi juga upaya penyeragaman dan pembakuan struktur program dan kurikulum. ${ }^{38}$ Dengan demikian, menurut hemat penulis, proses integrasi pendidikan Islam ke dalam sistem pendidikan nasional telah terlaksana sejak lama yang terlihat pada kebijakan yang telah ditetapkan meskipun belum menyeluruh pada semua komponen kurikulum.

\section{SIMPULAN}

Sejarah masuknya Islam ke Indonesia menunjukkan keterkaitan fungsional antara dakwah dan pendidikan. Perkembangan pendidikan Islam dalam bingkai pendi- 
dikan nasional tidak terpisahkan dari peran penting organisasi pendidikan Islam seperti organisasi sekolah yang menyelenggarakan pendidikan Islam secara berjenjang dan organisasi non sekolah yang berorientasi dalam pembinaan pendidikan Islam seperti yang dapat diamati pada organisasi Nahdhatul Ulama dan Muhammadiyah.

Telaah aspek yuridis formal menunjukkan bahwa landasan pengembangan pendidikan Islam Indonesia menekankan pada dua sisi: pertama, landasan dasar ideal Alquran, hadis, ijtihad, dan ijma para ulama serta perundang-undangan yang ditetapkan pemerintah. Kedua, landasan dasar operasional mencakup landasan historis, landasan filosofis, landasan psikologis, dan landasan filosofis. Secara subtantif muatan dari kedua landasan tersebut, hakikatnya menggambarkan kedudukan pendidikan Islam dalam sejarah pengembangan pendidikan nasional.

\section{CATATAN AKHIR}

1. Hasbulah, Sejarah Pendidikan Islam Indonesia Lintas Sejarah Pertumbuhan dan Perkembangannya, Cet. 1; Jakarta: PT Rajagrafindo Persada, 1995, h. 1.

2. Ibid., h. 2.

3. Pius A Partanto dan M. Dahlan Al Barry, Kamus Ilmiah Populer, Surabaya: Arkola, 2001, h. 696.

4. Harun Asrohan, Sejarah Pendidikan Islam, Cet. I; Jakarta: PT Logos Wacana Ilmu, 1999, h. 144.

5. "Pendidikan Islam", http://rizkyel-guaje.blogspot.com/2013/06/perkembangan-pendidikan-Islam-di.html. Diakses (14 April 2014).

6. BP3K Depdikbud, Pendidikan Islam dari Zaman ke Zaman, Jakarta, 1997, h. 31.

7. Hasbulah, Op. Cit., h. 19.

8. Mukti Ali, Alam Pikiran Islam Modern di Indonesia, Jakarta: Tinta Mas, 1947, h. 6.

9. Saifuddin Zuhri, Sejarah Kebangkitan Islam dan Perkembangnnya di Indonesia, Jakarta, 1978, h. 194.

10. Hasbulah, Op. Cit., h. 21.

11. Zuhairini, Sejarah Pendidikan Islam, Cet. VI; Jakarta: PT Bumi Aksara, 2000, h. 146.

12. Moh. Kasiram, dkk., Sejarah Pendidikan Islam, Cet. II; Jakarta: DIRJEN Pembinaan Kelembagaan Agama Islam, 1986, 147.

13. Zuhairini, Op. Cit., h. 148.

14. "Pendidikan Islam", http://abidmenulis.blogspot.com/2012/06/perkembangan-pendidikan-Islam-di_06.html. Diakses (16 April 2014).

15. Moh. Kasiram, Op. Cit., h. 150.

16. Hasbulah, Op. Cit., h. 65.

17. Ramayulis, Sejarah Pendidikan Islam: Perubahan Konsep, Filsafat, dan Metodologi dari Era Nabi Muhammad saw. sampai Ulama Nusantara, Cet. I; Jakarta: Kalam Mulia, 2012, h. 345.

18. Harun Asrohan, Op. Cit.., h. 177-178.

19.Samsul Nizar, Sejarah Pendidikan Islam Menelusuri Sejarah Pendidikan Era Rasulullah Sampai Indonesia, Cet. IV; Jakarta: Kencana Prenada Media Group, 2011, h. 345.

20. Ibid., h. 349.

21. Hasbulah, Op. Cit., h. 80.

22. Zuhairini, Op. Cit., h. 155. 
23. Moh. Kasiram, dkk., Op. Cit., h. 157.

24. Samsul Nizar, Op. Cit., h. 352.

25. Jumhur dan Danassuprata, Sejarah Pendidikan, Cet. II; Bandung: Jakarta Pen Cerdas, 1961, h. 121.

26. Deliar Noer, Gerakan Modern Islam Di Indonesia 1900-1942, Jakarta: LP3ES, 1982, h. 69.

27. Hasbulah, Op. Cit., h. 100.

28. Chairil Anan, Pertumbuhan dan Perkembangan Nahdatul Ulama, Solo: Jatayu, 1985, h. 135.

29. Hasbulah, Op. Cit., h. 117.

30. Landasan Pendidikan Islam", http://berbagi-makalah.blogspot.com/2013/03/landasanlandasan-pendidikan-dalam-islam.html. diakses (20 Mei 2013).

31. Ibid.,

32. Lihat Moh. Kasiram, dkk., Op. Cit.., h. 212.

33. Ahmad Tafsir, Ilmu Pendidikan dalam Perspektif Islam, Cet. IX; Bandung: PT Remaja Rosdakarya, 2010, h. 48.

34. Zuhairini, Op. Cit.., h. 218.

35. Lihat Moh. Kasiram, dkk., Op. Cit., h. 223.

36. Mastuhu, Memberdayakan Sistem Pendidikan Islam Strategi Budaya Menuju Masyarakat Akademik, Cet. 1; Jakarta: PT Logos Wacana Ilmu, 1999, h. 31.

37. Harun Asrohan, Op. Cit., h. 198-199.

38. Ibid., h. 200.

\section{DAFTAR PUSTAKA}

Ali, Mukti. Alam Pikiran Islam Modern di Indonesia. Jakarta: Tinta Mas, 1947.

Anan, Chairil. Pertumbuhan dan Perkembangan Nahdatul Ulama. Solo: Jatayu, 1985.

Asrohan, Harun. Sejarah Pendidikan Islam. Cet. I; Jakarta: PT Logos Wacana Ilmu, 1999. BP3K Depdikbud, Pendidikan Islam Dari Zaman Ke Zaman. Jakarta, 1997.

Daulay, Haidar Putra. Pendidikan Islam di Indonesia. Bandung: Cita Pustaka Media, 2001.

Hasbulah. Seajarah Pendidikan Islam Indonesia Lintas Sejarah Pertumbuhan dan Perkembangannya. Cet. 1; Jakarta: PT Rajagrafindo Persada, 1995.

Jumhur dan Danassuprata. Sejarah Pendidikan. Cet. II; Bandung: Jakarta Pen Cerdas, 1961.

Kasiram, Moh. dkk., Sejarah Pendidikan Islam. Cet. II; Jakarta: Dirjen Pembinaan Kelembagaan Agama Islam, 1986.

Landasan Pendidikan Islam. http://berbagi-makalah.blogspot.com/2013/03/landasanlandasan-pendidikan-dalam-Islam.html (diakses 20 Mei 2013).

Mastuhu, Memberdayakan Sistem Pendidikan Islam Strategi Budaya Menuju Masyarakat Akademik. Cet. 1; Jakarta: PT Logos Wacana Ilmu, 1999.

Nata, Abuddin. Tokoh-Tokoh Pembaruan Pendidikan Islam di Indonesia. Cet. I; Jakarta: PT Rajagrafindo Persada, 2005.

Nizar, Samsul Sejarah Pendidikan Islam Menelusuri Sejarah Pendidikan Era Rasulullah Sampai Indonesia. Cet. IV; Jakarta: Kencana Prenada Media Group, 2011.

Noer, Deliar. Gerakan Modern Islam di Indonesia 1900-1942. Jakarta: LP3ES, 1982. 
Partanto, Pius A dan M. Dahlan Al Barry, Kamus Ilmiah Populer. Surabaya: Arkola, 2001.

Pendidikan Islam, http://abidmenulis.blogspot.com/2012/06/perkembanganpendidikan-Islam-di_06.html. Diakses (16 April 2014).

Pendidikan Islam. http://rizkyel-guaje.blogspot.com/2013/06/perkembanganpendidikan-Islam-di.html. Diakses (14 April 2014).

Tafsir, Ahmad. Ilmu Pendidikan dalam Perspektif Islam. Cet. IX; Bandung: PT Remaja Rosdakarya, 2010.

Zuhairini, Sejarah Pendidikan Islam. Cet. VI; Jakarta: PT Bumi Aksara, 2000.

Zuhri, Saifuddin. Sejarah Kebangkitan Islam dan Perkembangnnya di Indonesia. Jakarta, 1978. 